\title{
PENGAMBILAN MINYAK KEDELAI DARI AMPAS TAHU SEBAGAI BAHAN BAKU PEMBUATAN BIODIESEL
}

\author{
Luqman Buchori*), Setia Budi Sasongko, Didi Dwi Anggoro dan Nita Aryanti
}

Jurusan Teknik Kimia Fakultas Teknik UNDIP

Jl. Prof. Soedharto, SH, Tembalang - Semarang; Telp. (024)7460058; fax. (024)76480675

*)E-mail : luqmanbuchori@undip.ac.id

\begin{abstract}
ABSTRAK
Kedelai adalah komoditi terbesar setelah padi di Indonesia. Kebutuhannya mencapai 2,3 juta ton per tahun. Dari jumlah tersebut 50\% dikonsumsi berupa tempe, 40\% berupa tahu, dan 10\% berupa minyak kedelai. Dari produksi tahu, dihasilkan limbah ampas tahu. Dalam penelitian ini, lemak pada ampas tahu diekstraksi untuk mendapatkan minyak kedelai yang dijadikan bahan baku biodiesel. Hasil ekstraksi kemudian dianalisa untuk dibandingkan dengan standar bahan baku biodiesel. Penelitian ini bertujuan untuk menghitung berat lemak yang terekstrak dari ampas tahu terhadap lama waktu ekstraksi dan jenis solven yang digunakan, serta mengetahui komposisi minyak ampas tahu tersebut. Hasil penelitian menunjukan bahwa waktu ekstraksi dan jenis solven mempengaruhi jumlah lemak yang dapat terekstrak. Benzene merupakan solven yang dapat mengekstrak minyak lebih baik daripada solven toluene dan $n$-heksane. Solven benzene memiliki waktu optimum lima jam untuk mengekstrak lemak yang terdapat di dalam ampas tahu. Dari hasil analisa, diketahui bahwa kadar FFA minyak kedelai yang menggunakan solven benzene sebesar 4,8\%, lebih kecil daripada menggunakan solven toluene (5,4\%) dan n-heksan $(5,8 \%)$. Sedangkan bilangan penyabunan diperoleh 184,22 mgKOH/gr untuk benzene, 193,55 mgKOH/gr untuk toluene dan $184,22 \mathrm{mgKOH} / \mathrm{gr}$ untuk $n$-heksan. Kandungan posfor yang didapat sebesar 0,19 untuk benzene, 0,23 untuk toluene dan $0,12 \%$ untuk $n$-heksan. Nilai ini masih dalam kategori besar sehingga harus melewati pretreatment terlebih dahulu sebelum melewati proses transesterifikasi menjadi biodiesel.
\end{abstract}

Kata Kunci: ampas tahu; biodiesel; kedelai; minyak kedelai; transesterifikasi

\begin{abstract}
Soybeans are the largest commodity after rice in Indonesia. Needs to reach 2.3 million tons per year. Of this amount $50 \%$ is consumed in the form of tempeh, $40 \%$ in the form of knowing, and $10 \%$ of soybean oil. From tofu production, tofu waste generated. In this study, fat on tofu extracted for soybean oil used as biodiesel feedstock. The results are then analyzed for compared to standard biodiesel feedstock. This study aimed to calculate the weight of fat extracted from the tofu waste to extraction time and the type of solvent and determines the composition of the oil tofu. The results showed that the extraction time and the type of solvent affects the amount of fat that can be extracted. Benzene is a solvent that can extract oil better than the solvents toluene and $n$-hexane. Benzene had five hours optimum to extract the fat in the tofu. From the analysis, it is known that the FFA content of soybean oil using benzene was 4.8\%, smaller than toluene (5.4\%) and n-heksane (5.8\%). While these numbers obtained by saponification $184.22 \mathrm{mgKOH} / \mathrm{gr}$ for benzene, $193.55 \mathrm{mgKOH} / \mathrm{gr}$ for toluene and $184.22 \mathrm{mgKOH} / \mathrm{gr}$ for $\mathrm{n}$-heksane. The content of phosphorus of 0.19 for benzene, 0.23 for toluene and $0.12 \%$ for $n$-heksane. This value is still in the major categories that must be passed before pretreatment process trough transesterification into biodiesel.
\end{abstract}

Keywords: tofu waste; biodiesel; soybean; soybean oil; transesterification

\section{PENDAHULUAN}

Kedelai adalah salah satu komoditi pangan utama Indonesia setelah padi. Konsumsi kedelai pada tahun 2009 mencapai 2,3 juta ton per tahun. Dari jumlah ini, 50\% dikonsumsi berupa tempe, $40 \%$ berupa tahu dan $10 \%$ berupa produk kedelai lainnya seperti minyak kedelai (Ekasari, 2009). Untuk memenuhi kebutuhan tersebut, Indonesia menempuh cara impor kedelai sebanyak sejuta ton pada tahun 2010 (http://kabarindonesia. com/beritaphp?pil=10\& rublik=ekonomi). Selain itu untuk menurunkan harga kedelai, pemerintah menetapkan kebijakan menurunkan bea masuk kedelai dari 10\% menjadi $0 \%$. Ketergantungan kepada bahan pangan dari luar negeri dalam jumlah besar dengan bea masuk 0\% akan melumpuhkan ketahanan nasional dan mengganggu stabilitas sosial, ekonomi dan politik. Oleh karena itu, perlu 
dicari solusi atas masalah tersebut tanpa mengurangi jumlah konsumsi kedelai.

Di samping itu, konsumsi masyarakat yang tinggi terhadap kedelai berupa tempe dan tahu menyebabkan banyak pabrik-pabrik tempe dan tahu didirikan di Indonesia. Pada pabrik pembuatan tempe, dipastikan hampir tidak menghasilkan limbah. Sedangkan untuk pabrik tahu, dalam pembuatannya menghasilkan hasil samping berupa limbah pabrik tahu. Limbah pabrik tahu terdiri dari limbah cair dan ampas tahu yang berkisar antara $25-67 \%$ produksi (http://cisaruafarm. com/bahan-bakupakan/ampas-tahu/). Menurut data Biro Pusat Statistik, pada tahun 1990 ampas tahu yang diperoleh sebagai hasil samping proses pembuatan tahu adalah sebanyak 13.057 ton, (Jenie dkk., 1994) sedangkan pada tahun 1999 adalah sebanyak 731.501 ton (Tarmidi, 2003). Terjadi peningkatan sebesar 700.000 ton dalam jangka waktu 9 tahun.

Selama ini, limbah cair tahu telah dimanfaatkan untuk pembuatan biogas dan bahan penggumpal lateks. Sedangkan untuk limbah ampas tahu sendiri hanya digunakan sebatas untuk pakan ternak atau digunakan untuk pembuatan tempe gembus yang tentu nilai ekonominya relatif kecil. Padahal ampas tahu masih mengandung bahan organik yang memiliki banyak manfaat. Komponen anorganik antara lain adalah kalsium, posfor, dan lain-lain. Sedangkan komponen organik yang dimaksud antara lain lemak dan protein. Protein dalam ampas tahu inilah yang menjadi pertimbangan produksi tempe gembus, sedangkan lemak dalam ampas tahu masih sedikit di kembangkan menjadi sesuatu yang bernilai lebih.

Lemak dalam ampas tahu tersebut dapat diekstraks untuk mendapatkan minyak kedelai. Minyak kedelai dari ampas tahu dapat dimanfaatkan lebih lanjut sebagai bahan baku biodiesel. Alternatif bahan baku minyak kedelai dari ampas tahu ini diperkirakan dapat mengurangi kebutuhan impor kedelai hingga $20 \%$. Pengambilan minyak kedelai dalam ampas tahu dapat dilakukan dengan cara ekstraksi. Ekstraksi lemak dilakukan dengan cara ekstraksi leaching menggunakan soxhlet ekstraktor. Solven yang dipakai berupa solven organik non-polar yang polaritasnya sama, seperti dietil eter $\left(\mathrm{C}_{2} \mathrm{H}_{5} \mathrm{OC}_{2} \mathrm{H}_{5}\right)$, kloroform $\left(\mathrm{CHCl}_{3}\right)$, benzena $\left(\mathrm{C}_{6} \mathrm{H}_{6}\right)$, n-heksana $\left(\mathrm{C}_{6} \mathrm{H}_{14}\right)$ (Karim dan Robiah, 2009).

\section{METODE PENELITIAN}

(C) 2012, Program Studi Ilmu Lingkungan Program Pasca Sarjana UNDIP
Bahan yang diperlukan dalam penelitian ini adalah ampas tahu, n-heksan, benzene dan toluene. Penelitian dilakukan dengan menggunakan variabel tetap yaitu berat sampel 10 gr; suhu ekstraksi pada titik didih masingmasing solven dan volume solven sebanyak 250 $\mathrm{mL}$. Sedangkan variabel berubah yang digunakan adalah jenis solven (n-heksan, benzene, toluen) dan waktu ekstraksi (1, 2, 3, 4). Adapun rangkaian alat yang digunakan dapat dilihat pada Gambar 1 dan 2.

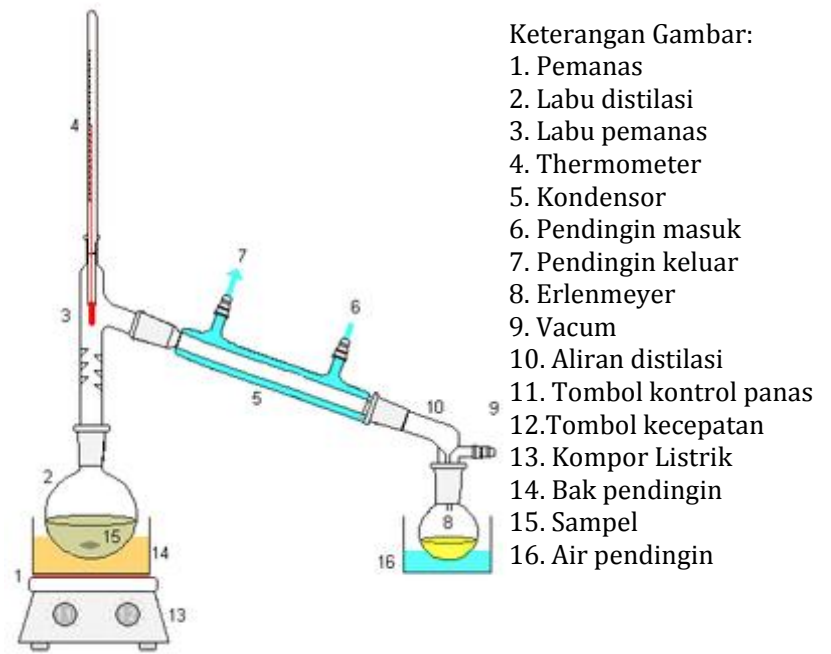

Gambar 1. Rangkaian alat distilasi

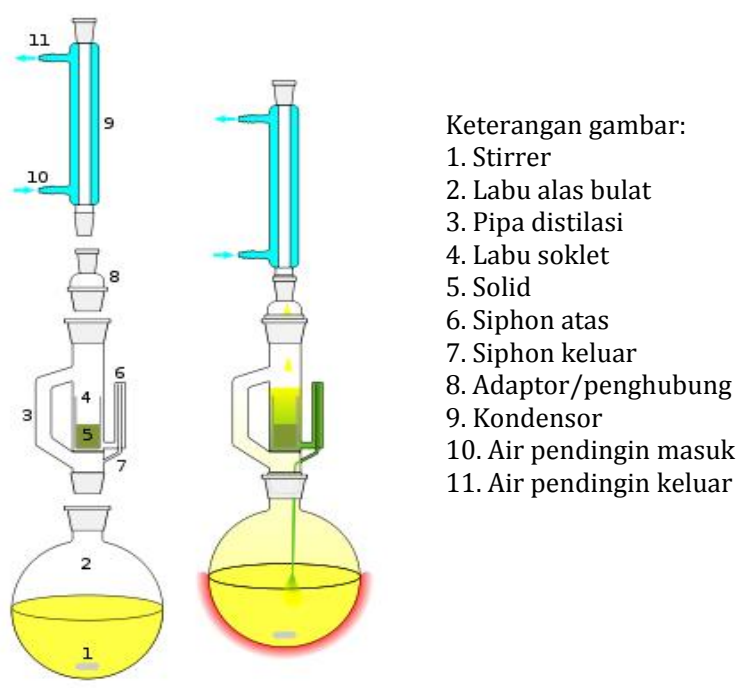

Gambar 2. Alat Ekstraksi

Langkah awal dalam penelitian ini adalah memisahkan ampas tahu dari limbah cair dengan menggunakan saringan. Kemudian mempersiapkan solven yang digunakan. Solven didistilasikan pada titik didihnya. Distilat yang diperoleh ditampung sampai volume $250 \mathrm{~mL}$. Tahap selanjutnya adalah mengekstraksi ampas tahu sebanyak 10 gr yang telah dikeringkan terlebih dahulu. Ekstraksi dilakukan dengan solven yang telah ditentukan yaitu benzene, 
toluene, dan n-heksan. Ekstraksi dilakukan selama 1-4 jam. Langkah akhir dari penelitian ini adalah memisahkan minyak yang didapat dari solven dengan cara distilasi. Distilasi dilakukan pada suhu titik didih solven yang digunakan. Ekstraksi dihentikan ketika cairan distilasi agak pekat. Kemudian hasil dari ekstraksi didistilasi hingga didapatkan minyak. Untuk mengetahui kualitas dari minyak kedelai yang didapat apakah sudah memenuhi standar bahan baku untuk dijadikan biodiesel atau belum dilakukan dengan cara analisa nilai FFA, bilangan penyabunan dan phospor.

\section{HASIL DAN PEMBAHASAN}

\section{Pengaruh Waktu dan Jenis Solven}

Pengaruh waktu ekstraksi dan jenis solven terhadap berat lemak terekstrak ditunjukkan pada Gambar 3.

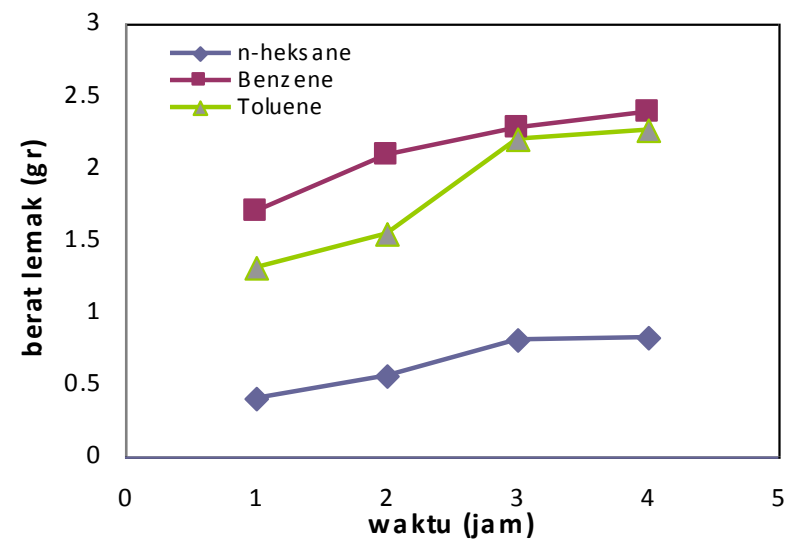

Gambar 3. Pengaruh waktu ekstraksi dan jenis solven terhadap berat lemak terekstrak

Dari Gambar 3 terlihat bahwa waktu ekstraksi dan jenis solven berpengaruh pada hasil berat lemak yang dapat terekstrak. Pemaikaian solven benzene lebih baik dari pada solven toluene dan n-heksane karena momen dipol benzene sama dengan momen dipol minyak kedelai yaitu 0 Dipol (D). Semakin bertambahnya waktu ekstraksi, maka semakin banyak pula jumlah recycle yang terjadi pada proses tersebut. Hal ini menyebabkan lemak yang ikut terekstrak juga semakin bertambah. Untuk ketiga jenis solven, waktu ekstraksi satu sampai dengan empat jam belum didapatkan waktu yang optimum. Maka dalam penelitian selanjutnya, perlu dicari waktu optimum untuk solven terbaik, dalam hal ini solven terbaik adalah benzene.

\section{Optimasi Waktu Ekstraksi}

(C) 2012, Program Studi Ilmu Lingkungan Program Pasca Sarjana UNDIP
Waktu optimum solven benzene dapat mengekstrak lemak terlihat pada Gambar 4.

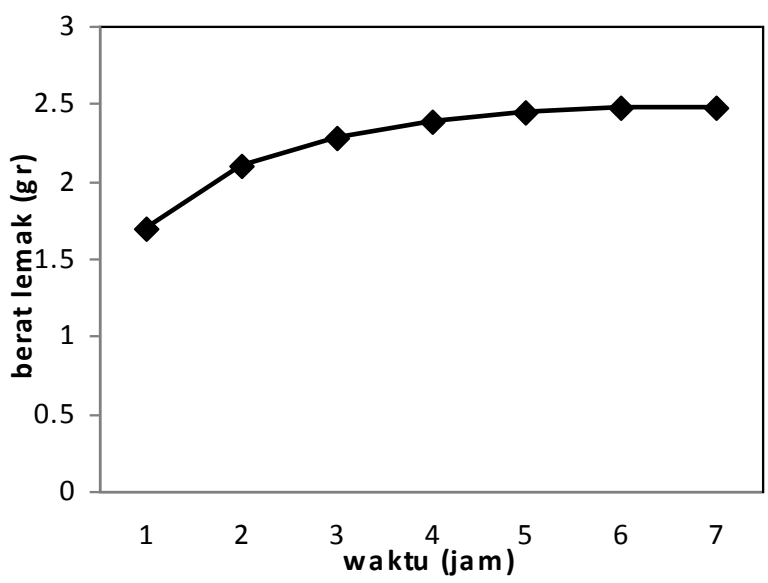

Gambar 4. Hubungan waktu ekstraksi vs berat lemak terekstrak pada pemakaian solven benzene

Gambar 4 menunjukkan bahwa waktu ekstraksi satu jam dapat mengeksrak lemak sebanyak 1,7 gram dari 10 gram ampas tahu. Kemudian pada waktu ekstraksi yang lebih lama, berat lemak yang terekstrak semakin lama semakin naik. Dan pada waktu ekstraksi lima jam didapatkan berat lemak sebanyak 2,45 gram.

Waktu ekstraksi lima jam tersebut dapat dikatakan sudah mencapai waktu optimum karena penambahan berat lemak pada waktu yang lebih lama tidak menunjukan hasil yang signifikan. Dari Gambar 4 dapat dilihat bahwa setelah mencapai waktu ekstraksi lima jam, kenaikan dari garis linier menjadi landai. Maka dapat disimpulkan bahwa solven benzene memiliki waktu optimum lima jam untuk mengekstrak lemak yang terdapat di dalam ampas tahu.

\section{Analisa Minyak Ampas Tahu}

Hasil analisa minyak ampas tahu disajikan pada Tabel 1.

Tabel 1. Hasil analisa minyak ampas tahu

\begin{tabular}{lccc}
\hline \multirow{2}{*}{ Komposisi } & \multicolumn{3}{c}{ Solven yang digunakan } \\
\cline { 2 - 4 } & Benzene & Toluene & Heksane \\
\hline FFA (\%) & 4,8 & 5,4 & 5,8 \\
$\begin{array}{l}\text { Bilangan } \\
\text { Penyabunan }\end{array}$ & 184,22 & 193,55 & 184,22 \\
$\begin{array}{l}\text { (mgKOH/gr) } \\
\text { Posfor (\%) }\end{array}$ & 0,19 & 0,23 & 0,12 \\
\hline
\end{tabular}

Dari Tabel 1 dapat dilihat bahwa minyak yang didapat dari ekstraksi ampas tahu memiliki 
kadar FFA yang berbeda-beda. Pada ekstraksi dengan solven benzene mengandung FFA 4,8\%, toluene 5,4\%, dan n-heksane 5,8\%. Kadar FFA maksimal pada bahan baku yang akan diproses menjadi biodiesel maksimal adalah 0,5\% (SRS Engineering Corp., 2008). Kadar FFA yang besar akan mengganggu pada proses pembentukan biodiesel, oleh karena itu pada minyak kedelai dari hasil ekstraksi perlu dilakukan pretreatment terlebih dahulu untuk mengurangi kadar FFA. Pretreatment yang dilakukan adalah dengan esterifikasi untuk mengurangi kadar FFA. Air yang menjadi hasil samping dipisahkan dari minyak kedelai. Setelah itu minyak kedelai siap untuk dilakukan transesterifikasi menjadi biodiesel.

Bilangan penyabunan erat kaitannya dengan kandungan FFA dan air, bilangan penyabunan yang besar dapat mengganggu proses pembentukan biodiesel. Bilangan penyabunan dapat dikurangi dengan cara pretreatment terlebih dahulu dengan mengurangi kandungan air dan FFA. Berkurangnya kandungan FFA dan air pada bahan baku untuk biodiesel akan mengurangi bilangan penyabunan juga. Oleh karena itu bila ditinjau dari angka bilangan penyabunannya, minyak kedelai yang diekstrak dengan ketiga solven yang berbeda perlu dilakukan pretreatment terlebih dahulu.

Sedangkan untuk kandungan posfor, ketiga minyak kedelai dengan solven yang berbeda menunjukkan persentase yang tidak terlalu besar. Kandungan posfor yang terdapat pada bahan baku biodiesel dapat mengganggu pada proses pemisahan biodiesel dengan gliserol. Namun, kandungan posfor dapat dihilangkan dengan proses yang disebut degumming.

\section{KESIMPULAN DAN SARAN Kesimpulan}

Dari penelitian ini dapat disimpulkan bahwa jenis solven yang digunakan untuk mengekstrak lemak berpengaruh terhadap berat lemak yang dapat terekstrak. Dari ketiga jenis solven yang digunakan, benzene merupakan solven yang dapat mengekstrak lemak lebih baik dari pada solven toluene dan n-heksan karena momen dipol benzene dan lemak sama yaitu $0 \mathrm{D}$ (Dipol). Lama waktu ekstraksi terhadap berat lemak yang terekstrak berbanding lurus sehingga semakin lama waktu maka berat lemak yang didapatkan semakin banyak. Ekstraksi menggunakan solven benzene diperoleh waktu optimum lima jam untuk mengekstrak lemak yang terdapat di dalam ampas tahu. Kadar FFA, bilangan penyabunan, dan kandungan posfor berturut-turut pada minyak ampas tahu dengan solven benzene didapatkan sebesar 4,8\%, 184,22 $\mathrm{mgKOH} / \mathrm{gr}, 0,19 \%$, dengan solven toluene 5,4\%, $193,55 \mathrm{mgKOH} / \mathrm{gr}, 0,23 \%$ dan dengan solven $\mathrm{n}$ heksan 5,8\%, 184,22 mgKOH/gr, 0,12\%. Dengan demikian, minyak kedelai dari ampas tahu harus melalui tahap pretreatment terlebih dahulu sebelum memasuki tahap transesterifikasi.

\section{Saran}

Dalam proses ekstraksi, pastikan luas permukaan ampas tahu besar, untuk memudahkan dalam mengestrak lemak. Solven yang sebaiknya digunakan dalah solven yang memiliki momen dipol sama dengan bahan yang akan diekstrak.

\section{UCAPAN TERIMA KASIH}

Ucapan terima kasih ditujukan kepada Fakultas Teknik Universitas Diponegoro Semarang yang telah membiayai kegiatan ini melalui Penelitian Jurusan Teknik Kimia Fakultas Teknik Undip sesuai dengan Surat Perjanjian Nomor : 4524/UN7.3.3/PG/2012 tanggal 7 Mei 2012.

\section{DAFTAR PUSTAKA}

Ekasari, Y., 2009, Pengaruh Lama Fermentasi Rhizopus Oligosporus Terhadap Kadar Oligosakarida dan Sifat Sensorik Tepung Tempe Kedelai, Laporan Tugas Akhir, Program Studi S1 gizi, Fakultas Ilmu Kesehatan, Universitas Muhammadiyah Surakarta.

http://kabarindonesia.com/beritaphp?pil=10\&ru blik=ekonomi

http://cisaruafarm.com/bahan-bakupakan/ampas-tahu/

Jenie, B.S.L., Ridawati, dan Rahayu, W.P., 1994, Produksi Angkak oleh Monascus purpureus dalam Medium Limbah Cair Tapioka, Ampas Tapioka, dan Ampas Tahu, Buletin Teknologi dan Industri Pangan, Vol. V no.3.

Kariem, M.A. dan Robiah, 2009, Distribusi Minyak Kedelai pada Proses Ekstraksi. Prosiding Seminar Nasional Teknik Kimia Indonesia, Bandung.

SRS Engineering Corporation, 2008, Feedstock Pretreatment-Biodiesel Technology, Patent Pending Technology, USA. 
Tarmidi, A.R., 2003, Penggunaan Ampas Tahu dan Pengaruhnya pada Pakan Ruminansia, Laporan Penelitian, Universitas Padjajaran, Bandung. 